\title{
OF GODS AND MEN: MONSTERS IN MARY SHELLEY'S FRANKENSTEIN AND RIDLEY SCOTT'S PROMETHEUS
}

\author{
Seda Pekşen \\ Ankara Üniversitesi
}

\begin{abstract}
This article is a comparison between Mary Shelley's Frankenstein and the 2012 Ridley Scott movie Prometheus focusing on the destructive consequences of the conflict between the creators and the created each deeming the other as monstrous. Both the novel and the movie are about finding answers to fundamental questions as to one's nature of existence motivated by a human curiosity and desire for immortality leading to a conflict with one's creator. The main concern here is to lay bare the blurriness of the lines allegedly separating the monsters from their creators, elucidating the monstrosity of the creators themselves as a product of hubris which eventually leads to a transgression of the boundaries between God/man, man/monster, good/evil and so forth.
\end{abstract}

KEYWORDS: monsters, others, hubris, Frankenstein, Prometheus

De dioses y hombres: monstruos en Frankenstein de Mary Shelley y Prometheus de Ridley Scott

RESUMEN: Este artículo es una comparación entre Frankenstein, de Mary Shelley, y la película Prometheus, de Ridley Scott, de 2012, centrada en las consecuencias destructivas del conflicto entre los creadores y los creados, cada uno de los cuales considera al otro como monstruoso. Tanto la novela como la película tratan sobre la búsqueda de respuestas a preguntas fundamentales sobre la naturaleza de la existencia motivadas por la curiosidad humana y el deseo de inmortalidad que conducen a un conflicto con el propio creador. La principal preocupación aquí es poner al descubierto la difuminación de las líneas que supuestamente separan a los monstruos de sus creadores, dilucidando la monstruosidad de los propios creadores como producto de la arrogancia que finalmente conduce a una transgresión de los límites entre Dios/hombre, hombre/monstruo, $\mathrm{bien} / \mathrm{mal}$, etc.

PALABRAS CLAVE: monstruos, los otros, arrogancia, Frankenstein, Prometheus 


\section{INTRODUCTION}

I teach you the Superman. Man is something that should be overcome. What have you done to overcome him? All creatures hitherto have created something beyond themselves: and do you want to be the ebb of this great tide, and return to the animals rather than overcome man? (Nietzsche, 1961, 41).

Humankind has always been curious about its own origins and asked the question "where did we come from?"; a question many children ask their parents. It is the question both Victor Frankenstein and his monster in Mary Shelley's novel Frankenstein (1818), as well as the lead character Elizabeth Shaw in Ridley Scott's 2012 movie Prometheus ask. ${ }^{1}$ According to one version of the Prometheus myth, the titan kindles the industrial growth of humans by offering them the gift of fire; however, the rapid advance of civilization brings with it destruction. In her story of the modern Prometheus Shelley replaces the Promethean fire with electricity -an unknown territory in her time. Not only in Shelley's novel, but in reality as well, progress opens the doors to the unknown and hence intensifies the curiosity that goes hand in hand with hubris. As more boundaries are transgressed, curiosity begins to be replaced by a fear of the unknown; thus, the journey that begins with a question about one's origins carries one further away from the answer, the people and finally from his/her own self. The image of an outcast, madly searching for answers at the expense of consuming his/her own life force, along with others', is monstrous. That is why, I will argue that both in the novel and the movie the same motivation - curiosity, the desire for immortality and hubris - causes not just the protagonist/antagonist but several characters to turn into monsters, while they themselves persistently put the blame on each other: their creators, parents or their own creations. My contention is that both the creators and the creations, the parents and the offspring are equally responsible for the chaos that ensues so long as they remain blind to the fact that they hold mirrors to one another to see the monster within themselves. Their inability, or unwillingness, to see the other as their own reflection leads to abandonment and estrangement on both sides. Rather than confronting the monster within, each accuses the other of being a monster, whereby they all become others, and consequently monsters.

Prometheus steals the heavenly fire from Zeus' hearth to help humankind with their progress; his punishment is a daily destruction and nightly restoration of his liver. It is Zeus's curiosity that finally sets Prometheus free: "for the secret which he [Prometheus] possessed concerning the ultimate fate of the dominion of Zeus, who, for the purpose of learning the secret, permitted Herakles to shoot the vulture, to free Prometheus, and bring him back to Olympos" (Murray, 1998, 207). The reason Zeus keeps the fire hidden from human beings in

\footnotetext{
${ }^{1}$ Prometheus, directed by Ridley Scott (USA: Twentieth Century Fox Film Corporation, 2012).
} 
the first place is his certainty that "the arrogance that would arise from the possession of so great a blessing” would be destructive (Murray, 1998, 206). Yet, humankind receives the knowledge of the fire and no matter how advanced civilization becomes, curiosity makes them keep turning backwards to question their origins. By questioning the original source of life and by finding the answer in galvanism, Victor Frankenstein ignites the fire of destruction. The question Frankenstein's Monster in the novel and Dr. Shaw in the movie ask are about their own personal origins. The Monster asks "Who was I? What was I? Whence did I come? What was my destination?" (Shelley, 2010, 112). Similarly Shaw, who thinks that the map they discovered in their archeological research is an invitation from the beings that, in her terms, "engineered" them, gets on board the space ship called Prometheus to meet her Makers in order to ask them for what purpose they created the humankind in the first place. The Monster and Shaw are driven by their curiosity as to the purpose of their own lives, whereas Frankenstein and Peter Weyland -the founder of the corporate financing the Prometheus mission - are both in search of the cure for death. As makers and parents at the same time -Frankenstein of the Monster and Weyland of Meredith Vickers, the corporate representative and David, the android - both men are in conflict with their children as well as with their own existence. They both play the part of the modern Prometheus by imitating the thief of fire who, in Weyland's words, wanted to create equality between humans and gods. Weyland, in his briefing at the start of the mission, claims that his purpose is to find the answers to where they came from, what their purpose is and what happens after death. The answers, apparently, stand for the mythological fire, since he defines the mission as the return of Prometheus. Just as in Prometheus' story, fire gives life on one hand but can be awfully destructive on the other. With reference to the novel, Irving H. Buchen argues "the common denominator that all the major and minor tales spin variations on is the hunger for completion" $(1977,105)$; in the case of the Monster and Shaw this would be the completion of the self through completing the gaps in the story of one's origins. However, as Donna Haraway argues, now that boundaries are transgressed we are all cyborgs, therefore we can no longer talk of others or differences, "an origin story in the 'Western', humanist sense [which] depends on the myth of original unity, fullness, bliss" (1991, 150-151) is irrelevant. Therefore, a search for such original unity would be futile, if not fatal. Blinded by their desire for completion, the characters of the novel and the movie fail to see that their ambition to solve the mystery of creation ironically leads them all -creators and their creations - to destruction by causing an even greater separation among them.

Frankenstein imagines himself as both a creator and a father at the beginning of his explorations: "A new species would bless me as its creator and source; many happy and excellent natures would owe their being to me. No father could claim the gratitude of his child so completely as I should deserve theirs" (Shelley, 2010, 42). Yet, his desire to create initiates his own downfall. Frankenstein's metaphorical downfall is depicted as a literal one in the opening scene of Scott's movie. The movie opens with a giant humanoid figure standing by the edge of a cliff. The humanoid drinks a dark liquid after which he completely disintegrates, his bits and pieces falling off the cliff into the waters below. When the camera zooms into the 
water, the bits of the giant are revealed as similar to human DNA. Thus, the humanoid sacrifices himself, for reasons that are not revealed in the movie, and at the cost of his own destruction originates a new life form, while an alien aircraft, presumably carrying the rest of his kind, vanishes into the sky. Whether literal or figurative, it is a fall, as it will bring even more destruction together with the evolution of human beings. In that sense it resonates with the various allusions to Milton's Paradise Lost in Shelley's novel; the fall of the humanoid thus might be seen as the fall of Adam from the Garden of Eden as a result of his desire for knowledge, as well as the fall of Satan as a result of his desire for power. At this point, another question that both the Monster and Shaw ask their Makers comes to mind. Upon finding out that the Engineers brought their own end via the weapons of mass destruction that they in fact meant to target at Earth, Shaw asks the one surviving Engineer why they were planning to destroy their own creations. Not the Engineer but David, the android, answers this question as follows: "Sometimes to create, one must first destroy" (Prometheus). This response resonates with the humanoid destroying himself in order to give life to a new species. The Monster's question to his own Maker is quite similar: "Yet you, my creator, detest and spurn me, thy creature, to whom thou art bound by ties only dissoluble by the annihilation of one of us. You purpose to kill me. How dare you sport thus with life?” (Shelley, 2010, 86). Both creators -the Engineer and Frankenstein- abandon their creations and cause their destruction as well as their own due to their desire for knowledge, immortality and power. Gods and those who aspire to gods destroy themselves along with whatever they created, pretty much like the modern human being gradually destroying Earth ever since the discovery of fire. The creators abhor their own creations and seeing them as monsters they either abandon their progeny, as Frankenstein does or seek out ways to annihilate them, as the Engineers do. However, what I will offer here is not a Christian or an allegorical reading of the original plot, nor will it be a criticism of science and technology or of irresponsible and neglectful parents. I will rather focus on the deeper implications of the conflict that turns into some sort of a vicious circle where the creator and the creation each see one another as monsters as a result of which creation and destruction become an inseparable binary.

\section{THE CREATORS AS MONSTERS}

The relationship between creators and creations can very well be seen as a parent-child relationship. Factoring in the relatively short existence of humankind on earth, and with reference to Arthur C. Clarke's Childhood's End in which alien overlords force the human race to evolve out of their childhood into maturity, it may even be suggested that human beings are still in their adolescence, in the process of growing up and evolving. Therefore, along with the actual parent-child relations - such as Frankenstein and his father in the novel or Weyland and Vickers in the movie - the relations between Prometheus and humankind, Frankenstein and his Monster, the Engineer and Shaw, Weyland and the android David can also be regarded the same way and as including similar conflicts. All these characters lack a mother figure in their lives and the fathers are either absent or monstrously authoritative. Fuller refers to 
Frankenstein's abandonment of his own creation as "a clear failure of his parental responsibility" (2003, 220). Frankenstein, though before the creation he was yearning for the gratitude of a child, fails to acknowledge his own responsibility towards his child. Even though he describes his own parents as exemplary in their moral responsibility to their family with a "deep consciousness of what they owed towards the being to which they had given life" (Shelley, 2010, 23), he does not follow their example. John A. Dussinger argues that Frankenstein's "intellectual pursuit is specifically a rebellion against the moral obligations between father and son" $(1976,38)$. Just as Prometheus defies Zeus' authority, Frankenstein defies his father's by pursuing the study of alchemy despite his father's objections. Frankenstein's father is "a parent who loves only conditionally" (Claridge, 1985, 18), since his idea of justice requires him to "approve highly to love strongly" (Shelley, 2010, 22). This, Frankenstein in a way copies from his father and not approving of his child, he chooses to reject him. The Monster, however, reminds Frankenstein of his responsibility when he commands his creator to create for him a female monster: "Do your duty towards me, and I will do mine towards you and the rest of mankind" (Shelley, 2010, 86). Like the love of Frankenstein and his father, the Monster's justice is also conditional.

While Frankenstein defies his father by performing a task he would never condone and also by attempting, albeit failing, to become the most gratitude-deserving father, in the movie Vickers and David literally kill themselves in their endeavour to be loved and approved by their father Weyland. Vickers, "the ice goddess" as Doherty puts it, "hates her father" (Doherty, 2012, 54-55). At the beginning of the movie Weyland refers to the android David as "the closest thing I have to a son" and it is only towards the end of the movie that we learn he in fact has a human child: Vickers. Even though they take the same journey on the same ship, Vickers is abandoned by her father and obviously makes an effort to please him and gain his love by imprisoning herself into the ship (her private quarters, though luxuriously decorated and capable of sustaining life support for a long period in the event of a disaster, is in a way her solitary confinement cell) and into her alienating position of power, which she seems to feel requires an inflated show of masculinity in an environment ruled by the law of the father; hence her ice-cold behavior towards the crew withholding any feminine quality such as empathy, affection, kindness, and warmth. ${ }^{2}$ Her rudimentary interaction with the crew does not show any sign of human touch; on the contrary, she acts like a machine with no emotions whatsoever, dedicated solely to the completion of her mission, which seems to be a desire stemming from her sense of incompletion for the lack of a loving father figure. David, on the other hand, though a machine, portrays a much more human role, passing "the time playing hoops, studying Sanskrit, and binge-viewing David Lean's Lawrence of Arabia (1962)" (Doherty, 2012, 54) while the crew is in hypersleep. However, causing Shaw's impregnation

${ }^{2}$ The distinction made between masculinity and femininity here does not denote a hierarchical binary, but a lack of balance in the individual psyche within the confines of the assumption that a healthy functioning psyche consists of a well-balanced combination of both masculine and feminine aspects regardless of the individual's biological sex. 
with an alien embryo by infecting her boyfriend, Holloway, David becomes not only "the agent of her lover's infection and thus the true father" (Doherty, 2012, 55), but a monstrous god as well. The monstrosity of this obedient son helping out his father in his monstrous pursuits is underlined when he says to Shaw "you must feel like your God abandoned you" as he gives her the news of her undesirable pregnancy (Prometheus).

Dr. Shaw seems to be the opposite of Frankenstein, Vickers and David, both in terms of her relationship with her father and with God. Unlike Vickers, "she loves her father" (Doherty, 2012, 55) whom she has lost to Ebola and she is a believer in search of the original Father. When she explains to the whole crew her hypothesis that the map they have discovered might be an invitation from the Engineers, the other scientists on board react against her putting forth the theories of Darwin. "How do you know?", they ask, to which she replies, “I don't. But I choose to believe" (Prometheus). Just like Frankenstein, Shaw is in search of "a force not scientific but divine" (Doherty, 2012, 53); however, instead of giving birth to the monster within her, she chooses to destroy it right from the start. Therefore, she seems to be the only character who does not turn into a monster while searching for the answer to the secrets of life. In that sense, it might be contended that her inability to conceive, which is revealed at the beginning of the movie in a conversation she has with Holloway, foreshadows symbolically that she will never become a creator, hence a monster. Yet, like all the monsters in the novel and in the movie, in the end she finds herself totally abandoned as the sole survivor, excluding David, who remains as nothing but a head. Halfway through the movie Holloway asks Shaw: "Don't you want to know why they abandoned us?" (Prometheus). To him, obviously, this is a more relevant question than how they were created. At that stage, Shaw is not concerned with that question, nor does she feel abandoned after her father's or Holloway's death as David presumes. She feels abandoned when the Engineer kills Weyland, rips off David's head and leaves without answering her question why they tried to kill their own creation; "Why do you hate us?", she asks (Prometheus). This is quite similar to the way Frankenstein's Monster feels when he realizes that his own creator abhors him Apparently, loneliness is a given for all kinds of monsters.

\section{THE CREATED MONSTERS}

The one surviving Engineer whom David awakens from his millennia of hypersleep, Weyland, Vickers, David, Frankenstein and his Monster all live in self-isolation in one way or another. They are either abandoned by their makers/parents or they choose to be isolated due to their monstrous ambitions. A third reason is that their monstrosity is only in the eye of the beholder, as is the case with Frankenstein's Monster. The Monster, when he is born, is but a monster only in appearance, which unfortunately brings him to the margins of the society. With his gigantic stature and his hideous complexion, he is shunned by anyone who sets eyes on him. Inside, however, he is as human as his creator, which is why he is able to establish a decent communication with Old De Lacey who, being blind, does not base his first impressions on prevalent social prejudices like the others, as he tells the Monster "the hearts of men, when 
unprejudiced by any obvious self-interest, are full of brotherly love and charity" (Shelley, 2010, 116). Yet, people are prejudiced; they turn away screaming the moment they set eyes on the Monster or blame him for all the evil and try to lynch him even though in reality he would be trying to help them, therefore "his aggression is a by-product of disintegration, not an innate drive that has been cathartically unbound" (Sherwin, 1981, 890). This again brings us back to the subject of incompletion and parental responsibility. The main ingredient in the making and raising of the creature is supposed to be love, which, similarly, seems to be what is lacking in the relationship between Weyland and Vickers as father and daughter. Love is what Shaw also seems to expect from her Maker when, just as the Monster, she sets forth to meet him; what she finds instead, just as the Monster, is hatred and a determination to destroy. The Monster says: "I was benevolent and good; misery made me a fiend. Make me happy, and I shall again be virtuous" (Shelley, 2010, 86). His misery is a result of his alienation which he wants to eliminate via a mate that would keep him company and not abandon him since they would be alike: "It is not, then, the monster's nature that makes him so vengeful, as his creator deludes himself into thinking, but rather his overwhelming sense of isolation and despair at lacking human connections that in fact his father should have first provided" (Claridge, 1985, 21). The same society that, through prejudice, increases the Monster's alienation and thus contributes to the transformation of a potential human into a fiend, turns a completely innocent individual, Justine, into a monster in the same manner. Having been discovered with Frankenstein's little brother's necklace in her pocket, in the eyes of the society Justine becomes a monster killing little boys; whereas, her execution despite her innocence underlines the monstrosity of society per se. What the society does to the Monster and to Justine is no different than what Frankenstein does to the Monster. The Monster describes his escape from the angry mob at a village as sheltering himself "from the barbarity of man" (Shelley, 2010, 92). Yet even then, he expects to receive love from the De Laceys, as he finds them superior to himself (Shelley, 2010, 100). When he is treated in the same brutal manner by that family as well and upon finding out the details of his creation in Frankenstein's journal, he thinks of himself in a much worse state than Satan who "had his companions, fellow-devils, to admire and encourage him; but I am solitary and abhorred" (Shelley, 2010, 113). His feelings of anger, hatred and revenge increase as a result, and thus a potentially benevolent human being is transformed into a monster by his creator and by the society he was born into.

Through his rejection of the Monster and his absence, Frankenstein, in a way, teaches his creature how to be monstrous by demonstration. Frankenstein admits that he "abhorred society" (Shelley, 2010, 143). By alienating himself in his laboratory for the sake of his grand project, he himself turns into a monster avoiding any kind of human interaction including his family members: "This ingressive movement is attended by self-loss, a radical shrinkage of his empirical self, and self-aggrandizement, a heightening of his isolate selfhood to daemonic status" (Sherwin, 1981, 892). Frankenstein alienates himself first to fulfill his plan, then because he tries to escape as far away from his hideous creation as he can, and finally due to the sense of guilt he experiences in relation to the crimes his monster commits. The lonelier he gets, the more monstrous he becomes; a solitary man, mad with anger and intent on 
revenge. The way Walton describes Frankenstein as they found him in the North Pole chasing the Monster is testimony to Frankenstein's monstrosity: "I never saw a more interesting creature; his eyes have generally an expression of wildness, and even madness" (Shelley, 2010, 15; emphasis mine). This is similar both in purpose and in outcome to the situation of Weyland and Vickers. Peter Weyland, a trillionaire, is surrounded by nurses and servants; still, he is a lonely man in pursuit of the secrets of heaven which, he believes, will provide him with the gift of immortality. In fact, Weyland's desire for immortality is represented via other means as well: founding a huge corporation under his name and building an android that is very hard to distinguish from a human being to serve him unquestioningly. Not only his ambitious goal and the steps he takes to reach it, but his appearance also is reason enough to think of him as a monster. Due to his old age his body is completely deformed, so much so that it almost suggests a defiance of God. Just like the Monster in the hovel near De Laceys' cottage, Weyland hides in the spaceship unbeknownst to the rest of the crew including his own daughter, but of course excluding his devoted servant/son David. His daughter, Vickers, similarly confines herself to her own quarters, choosing not to have any kind of human interaction with the rest of the crew -like father, like daughter. Her ice-cold manners, her lack of sympathy and her determination to complete the mission not only resemble her father's, but also give her a monstrous quality, the destructiveness of which is revealed towards the end when she selfishly fights for her own survival completely disregarding her fellow beings. Her abandonment by her father is very much like the Monster's abandonment by Frankenstein, and in order to get closer to him Vickers voluntarily becomes a part of the mission. Just like the Monster, her desire is to be loved and acknowledged. Therefore, the common point in the relations between creators and their creations is that the former leaves the latter behind only to come back to destroy them or to cause their destruction due to their own egotistical ambitions.

\section{OTHER AS MIRRORS TO THE MONSTERS WITHIN}

Both in the novel and in the movie the characters who demonstrate unrequited love are, ironically, the creations and not their creators. The Monster, Vickers and Shaw never give up on their love for their Makers, but they strive to understand the creators' motives and to make them show the tiniest indication of love. Oates, who also underlines the lack of responsibility on the creator's part in Shelley's novel, points to this irony which results in a vicious circle: "By contrast the demon is all activity, all yearning, all hope. His love for his maker is unrequited and seems incapable of making any impression upon Frankenstein; yet the demon never gives it up [...] his posture is always one of simple need: he requires love in order to become less monstrous, but, as he is a monster, love is denied him" $(1984,546)$.

Replacing the word "demon" with either Vickers or Shaw, and the name Frankenstein with either Weyland or the Engineer wouldn't be inappropriate. The Monster says to his creator: "You accuse me of murder, and yet you would, with a satisfied conscience, destroy 
your own creature" (Shelley, 2010, 87). Who, then, is the monster? The answer would be: they both are. Marshall Brown argues that "[b]y definition (and common usage in Shelley's day), a monster is a being without a place in the cosmic order" $(2003,156)$. Therefore, a monster is an Other; anyone who is a misfit would run the risk of being recognized as a monster. Once again, the conflict arises from the way people see things with prejudiced eyes, hence halfblind. In these stories of conflict between creators and creations the latter functions as a mirror image to the former. The creator refuses to see the reflection of his/her own image in the other; his/her own monstrosity, the dark and estranged self gazing back at them in the form of an Other. Ironically, both the monstrosity and the otherness are imposed on the creation by the creator per se. In the case of Justine, for instance, what she sees is her own reflection in the society as a monster. Her confessor pushes her so hard that she is left without a choice: "I almost began to think that I was the monster that he said I was" (Shelley, 2010, 72). As a result, she voluntarily becomes the monster they assume her to be and is executed. Similarly, the Monster first realizes his status as an Other when he sees his reflection in a pool of water: "I became fully convinced that I was in reality the monster that I am" (Shelley, 2010, 99). Just like Justine, the Monster adopts the judgment of the society and of his own maker, instead of them recognizing him as their own mirror image reflecting their own ugliness within, their potential for evil and their alienation. This is especially the case for his creator, as Frankenstein also admits that he is as guilty as his Monster for the crimes that are committed against his loved ones. He calls himself "the true murderer" and the dead the "victims to [his] unhallowed arts" (Shelley, 2010, 73-74). Yet, although he admits his guilt, he fails to realize that the Monster is "an outsized mirror image of his creator" (Oates, 1984, 552). When the first murder is committed, that of Frankenstein's brother William, the chase begins between the creator and his creation, throughout which they keep mirroring one another in their sense of guilt, hatred and desire for revenge upon the other, as well as in their alienation and monstrosity. In a process of self-education the Monster finds out that human beings can at once be "vicious and base" on one hand, "noble and godlike" (Shelley, 2010, 104) on the other, and this is ironically exemplified in the double image of Frankenstein and his Monster as they chase each other like a cat chasing its own tail. The conversations between Frankenstein and the Monster resemble a man talking to himself in the mirror; they curse each other, curse themselves, destroy each other and destroy themselves in the end. Both their monstrosity and their misery are identical.

In the movie when the crew finds the dead body of one of the Engineers, which in its ugly enormity resembles Frankenstein's Monster, their first reaction is that it is "remarkably human"; later the results of the autopsy reveal to Dr. Shaw that human beings "come from them" (Prometheus). However there seems to be another kind of resemblance between the two species besides the physical: their destructive tendencies. The crew has discovered the Engineers were planning to destroy life on Earth -their own creations. Shaw keeps asking why they would do such a thing. Why not? It is but a reflection of human beings doing the exact same thing - gradually destroying life on Earth - via wars, greenhouse gas emissions, overconsumption among other things. Human beings destroy their own environment, each 
other and themselves all the time, and the Engineer - because he is a giant and his destruction is mass murder - functions as a sort of a magnifying mirror to the current human condition, just like the oversized mirror of Frankenstein. Another non-human and monstrous entity in the movie is David, and because his design is flawless he stands out as a much better mirror image for the crew - especially for Holloway and Weyland. There is a constant skirmish between Dr. Holloway and David, whose "remarkably human" looks give Holloway the kind of disgust that Frankenstein has for his Monster. Holloway is angry to have no living Engineer left for him to ask the question why they made the humans. David, on the other hand, asks Holloway, who persistently reminds David that he is not real, the same question:

"Why do you think your people made me?".

"Because we could".

"Can you imagine how disappointing it would be for you to hear that from your creator?".

(Prometheus)

David, being super-intelligent, responds in a cool and rational manner, which is rather condescending than decent. Though Holloway fails to see it, David holds a mirror to him so that Holloway could see things from the Other's perspective. Yet it is not exactly an act of kindness, since David later infects Holloway with the sample he clandestinely brings in from the alien ship, thereby causing Holloway's painful death, in addition to the horrible impregnation of Shaw. He resembles both Frankenstein, focusing on his own kind of unhallowed arts, and the Monster saying "I am your master -obey!" (Shelley, 2010, 151). David is also a mirror reflecting the monstrous image of his Maker, Weyland, by unquestioningly fulfilling his commands, carrying out research at the cost of human beings so that Weyland could live forever, just like an android. Questioning the concept of free will in relation to Frankenstein's Monster, Oates asks: "is the demon psychologically his creature, committing the forbidden acts Frankenstein wants committed?" (Oates, 1984, 547). In the case of Weyland and David the answer would definitely be yes. What Weyland has designed in the form of David is, in fact, an embodied form of his own desires: an immortal, unaging, resilient existence. Oates refers to Frankenstein's Monster as "a manufactured nemesis" which again applies to the relationship between Weyland and David: "The monsters we create by way of an advanced technological civilization 'are' ourselves as we cannot hope to see ourselves -incomplete, blind, blighted, and, most of all, self-destructive” (Oates, 1984, 550).

\section{TRANSGRESSING THE BOUNDARIES}

Frankenstein, his Monster, Weyland, Vickers, David and the Engineers are all mirrors to one another. The reason they cannot see their own reflection in the other is that they are blinded by fear. Atwood suggests "[t]here must have been a very thin line between gods and monsters" when human beings were originating the first stories, because their worldview 
would "have contained many fears - fears of crossing boundaries, of offending divinities, of breaking taboos" $(2012,44)$. The same fears seem to be still prevalent. What the characters in question fear the most is the unknown that they encounter once boundaries are crossed. When they cross the boundaries on their own by creating mirror images for themselves, the unknown they stumble upon might be considered as the self; hence fear of the unknown becomes a fear of the (dark) self. The creator may be transgressing the boundaries and breaking the taboos by the simple act of creation, and so may the creature by simply turning against his own creator with destructive purposes. This is exactly the kind of fear, what Asimov calls "the Frankenstein complex" $(1984,27)$ that Holloway, for instance, feels in the presence of David, or the fear of the whole crew when they first encounter the Engineer. David is a cyborg who crosses the boundaries between human and machine, and therefore an unknown that would, for people like Holloway, "signal disturbingly and pleasurably tight coupling" (Haraway, 1991, 152). David also reminds human beings that they are not as intelligent or resilient, but quite fragile and, after all, mortal: "People are nowhere near so fluid, being both material and opaque. Cyborgs are ether, quintessence" (Haraway, 1991, 153). Thus, his presence creates not only "fear, love, and confusion" (Haraway, 1991, 178) but envy as well, since people find it difficult to accept the transgressed boundaries and see him as a reflection of their own potential to become cyborgs (not in the literal sense, but in terms of a perception of the world beyond differences as Haraway explains) rather than as the Other.

Frankenstein's Monster has a similar status that instigates fear, especially because of the way he was created: via the use of electricity, which is an unknown in the setting of the novel that attributes to him a machine-like quality. Fuller and Hammond both agree that Frankenstein's Monster can be regarded as a cyborg in the way that Haraway defines it (Fuller, 2003, 217; Hammond, 2004, 193). However, because others fail to see the resemblance between themselves and the Monster, to realize that they are cyborgs as well, that there are no boundaries or differences for that matter, they misinterpret his being:

Reading a sinister intention into this newborn's clumsy gestures, he [Frankenstein] is terrified by a shadow of his own casting, a bad interpretation that climaxes all the traumatic events and that irrevocably determines the creation as The Bad Event. [...] his imputation of diabolical designs to the Creature is a gross distortion, as is his summary judgment (Sherwin, 1981, 888).

Such distortion of the reality poses an obstacle in the way of understanding, as in the case of Justine as well. Frankenstein's project brings together "the human and the animal, the magical and the scientific", and as such the boundaries are seen as "violated" (Fuller, 2003, 218) rather than transgressed. The characters, who refuse to accept the transgression as a positive act bringing together the two sides of the mirror to reach the unity that has always been there, still need those boundaries in order to be able to define themselves in opposition to the Others. That is why the Monster's fragmented structure, which in the eyes of the others becomes an "embodiment of boundaries" (Fuller, 2003, 219), horrifies not only his creator 
but anyone else who gets in touch with him. In fact, what the structure of the Monster establishes for human beings to see is a quintessential unity, on the condition that the other acknowledges that they themselves are also an indispensable part of that unity. However, such an acknowledgement does not prove possible since it would require human beings to embrace their monstrous reflection and see the Monster as an embodiment of their own darkness. Therefore, the Monster remains fragmented and the distinction between good and evil is preserved, evil being assigned to the marginal Other. Thus the Monster, the unknown, the darkness, the evil is pushed away to the edge, so that people are not forced to face their own nature, which is quite paradoxical since it is that very nature they have been trying to figure out in the first place.

\section{CONCLUSION}

What seems to motivate characters like Frankenstein and Weyland in their godlike pursuits that turn them into destructive monsters and drive their creations towards monstrosities in return is their hubristic desire for immortality. It is this desire that raises their curiosity to the point of defying $\operatorname{god}(\mathrm{s})$, just as Prometheus did, by reaching for the forbidden fruit of the tree of knowledge: "A monster is that outcome or product of curiosity or epistemophilia pushed to an extreme that results [...] in confusion, blindness, and exile" (Brooks, 1993, 218). Both Frankenstein and the Monster, and the whole crew of the Prometheus are in some sort of exile -the former in the North Pole, the latter in space. Frankenstein and Weyland's Promethean defiance of god is an attempt at beating death, however, in human hands the spark of life ironically turns into a destructive tool. Their suffering does not have to be read as god's punishment the way Prometheus was punished, but could be considered a failure in finding the right method to get over one's incompletion. Frankenstein, for instance, fails to realize that eliminating the Other is not the solution when the purpose is to get over incompletion. In the case of both Frankenstein and Weyland, their self-alienation on its own is an indicator that these two aspiring men will ignore all the others along the way. This gives them, despite their curiosity, an "intermediate 'Promethean' status" (Miller, 1989, 66). Their desire for immortality obviously stems from a basic fear of death -the ultimate unknown - however, "desire cannot overcome the monstrous, but only reproduce it" (Brooks, 1978, 604). The Promethean fire they each discover turns their attention away from the binaries of the concrete world that are supposed to be united in order to reach the abstract world of immortality. In their hubris, they deny responsibility towards others, as a result of which they deny "the shadow-self locked within consciousness", and each becomes "a finite and flawed god at war with, and eventually overcome by, his creation" (Oates, 1984, 553). On the alien ship, when they meet the one surviving Engineer, Weyland says: "If they made us, then surely they can save us. Well, save me anyway. From death of course" (Prometheus). The whole human crew is on the verge of total destruction, yet regardless of their ordeal, Weyland refuses to leave without "answering the most meaningful 
questions ever asked by mankind" (Prometheus). The Engineer responds to his questions by violently killing him. His Maker is as monstrous as Weyland himself; as David comments at the end of the autopsy of the dead Engineer's head, their Makers are also "mortal after all" (Prometheus). Similarly, Vickers reminds his father of his own mortality right before he dies: "A king has his reign and then he dies. That is the natural order of things" (Prometheus). The extreme pride of all these Makers seems to blind them to the fact that they are creators/parents, but not immortal gods. At the end of the movie David suggests that "everybody wants their parents dead", especially if those parents are the cause of one's loneliness, abandonment, and consequent monstrosity (Prometheus). David himself thinks that when his Maker, Weyland, is no longer there to programme him he would be free. David, in fact, is the closest among them all to immortality, since he continues his existence even after his head is ripped off. Yet, he is as much of a monster as any other, because he brings destruction to the crew through the research he carries out to serve his Maker Weyland.

Frankenstein, at the beginning of his narrative, gives the impression that his purpose is to serve humankind. However, a closer look at his word choice reveals his rather hubristic tendencies: "I will pioneer a new way, explore unknown powers, and unfold to the world the deepest mysteries of creation" (Shelley, 2010, 37; emphasis mine). Taking into consideration his later denial of responsibility and watching him gradually turn into a vengeful monster, it would be safe to assume that, though he wasn't trying to create the superman, maybe he was attempting to become one himself, as shortly after he admits he was aspiring "to become greater than his nature will allow" (Shelley, 2010, 41). Although he aims at becoming some sort of a savior for the humankind, only at the thought of creating a female mate for his Monster does he realize that in so doing he would give the couple a similar creative power, and hence would instead become a curse of human existence. Frankenstein becomes a monster not just because of his mad and deadly pursuit of his offspring, but also because, as he himself admits, he is the cause of the suffering of William, Justine, Henry, and his father. He knows that he would have been treated exactly the same way his Monster is treated if only people knew: "How they would, each and all, abhor me, and hunt me from the world, did they know my unhallowed acts and the crimes which had their source in me!” (Shelley, 2010, 166). This is exactly what the Engineers, Weyland and David become in the eyes of the other characters. There seems to be a pattern in which one falls victim to his/her hubris and becomes a creator with the desire for immortality. When the creator proves unable to recognize his/her own image reflected by his/her creation, but denying responsibility turns away, the downfall begins. Consequently, the creator takes his/her creations down with him/herself, which is only appropriate since they are all two sides of one coin. Eventually, and ironically, what is created in the end is destruction.

The survivors of the novel and the movie are the Monster, Shaw, and David ('s head). They are the cyborgs in the Harawayan sense - the Others. Shaw too, because as a woman with no creative power and as an outside observer of the conflicts between all the monsters, she is an Other. Her only action of asking questions to the Engineer cannot be considered monstrous in any way, as opposed to the actions of Frankenstein, his Monster, the Engineers, 
Weyland, David and Vickers. Her motivation is curiosity, belief and love, and not a desire for immortality. Thus the three surviving Others are confined in solitude in the end, because the rest do not prove ready to grasp the real and maybe the most important secret of life under their circumstances: the monster you think you see before you, is indeed the monster within you. Therefore, there is no running away from it, whether in the North Pole or in outer space. David, free from his father's authority, is no longer obliged to carry out monstrous activities. Shaw remains as the exemplary faithful scientist, who is not the cause of the imminent destruction of Earth, but as implied at the end of the movie, might even be its savior. The Monster survives, probably because he was able to face the mirror, to see the monster in the human and the human in the monster. The overall implication is that human beings have to learn to live with the monsters within and without, instead of trying to annihilate them, because the alternative is solitary confinement. One must fearlessly transgress the boundaries, embrace the monster within, so that $\mathrm{s} /$ he will be able to embrace the monsters without and eliminate differences. Then there will be no more Others - be it gods, men, women, animals, monsters or machines. The solution for humankind is to move forward beyond themselves and to let it be the childhood's end.

\section{REFERENCES}

Asimov, I. 1984. How Did We Find Out About Robots? New York: Walker \& Company.

ATwOOD, M. 2012. In Other Worlds: SF and the Human Imagination. London: Virago Press.

BrooKs, P. 1978. "Godlike Science/Unhallowed Arts: Language and Monstrosity in Frankenstein", New Literary History, 9(3), pp. 591-605. https://doi.org/10.2307/468457.

BRoOKs, P. 1993. Body Work: Objects of Desire in Modern Narrative. Massachusetts: Harvard University Press.

Brown, M. 2003. “Frankenstein: A Child's Tale”, Novel: A Forum on Fiction, 36(2), pp. 145-175. https://doi.org/10.1215/ddnov.036020145.

Buchen, I. H. 1977. "Frankenstein and the Alchemy of Creation and Evolution", The Wordsworth Circle, 8(2), pp. 103-112. https://doi.org/10.1086/TWC24039234.

Claridge, L. P. 1985. "Parent-Child Tensions in Frankenstein: The Search for Communion", Studies in the Novel, 17(1), pp. 14-26.

DoherTy, T. 2012. “Prometheus by Ridley Scott, David Giler, Walter Hill, Jon Spaihts and Damon Lindelof” (review), Cinéaste. 37(4), pp. 53-55.

Dussinger, J. A. 1976. "Kinship and Guilt in Mary Shelley's Frankenstein”, Studies in the Novel, 8(1), pp. 38-55.

FULLER, S. C. 2003. "Reading the Cyborg in Mary Shelley's Frankenstein", Journal of the Fantastic in the Arts, 14(2), pp. 217-227.

HAMMOND, K. 2004. "Monsters of Modernity: Frankenstein and Modern Environmentalism", Cultural Geographies, 11(2), pp. 181-198. https://doi.org/10.1191/14744744004eu3010a. 
HaraWAY, D. J. 1991. "A Cyborg Manifesto: Science, Technology, and Socialist-Feminism in the Late Twentieth Century”, in Simians, Cyborgs, and Women: The Reinvention of Nature. New York: Routledge, pp. 149-181.

MilleR, R. 1989. "The Being and Becoming of Frankenstein", SubStance, 18(3), pp. 60-74. https://doi.org/10.2307/3685251.

MurraY, A. 1998. Who's Who in Mythology: Classic Guide to the Ancient World. Middlesex: Senate Press.

NiETZSCHE, F. 1961. Thus Spoke Zarathustra. London: Penguin Books.

OAtES, J. C. 1984. "Frankenstein's Fallen Angel", Critical Inquiry, 10(3), pp. 543-554. https://doi.org/10.1086/448261.

SCOTT, R., HILL, W. and GILER, D. (producers) and SCOTT, R. (director). 2012. Prometheus. United Kingdom/United States of America: Twentieth Century Fox Film Corporation.

SHELLEY, M. W. 2010. Frankenstein. London: Harper Press.

SHERwIN, P. 1981. "Frankenstein: Creation as Catastrophe", PMLA, 96(5), pp. 883-903. https://doi.org/10.2307/462130.

\section{ABOUT THE AUTOR}

Seda Pekşen is an Associate Professor of English Language and Literature at Ankara Üniversitesi, Faculty of Languages, History and Geography. She received her B. A. in 2000 from Ankara Üniversitesi, Faculty of Languages, History and Geography, Department of English Language and Literature; her M. A. in 2003 and her Phd in 2008 from Orta Doğu Teknik Üniversitesi, Department of Foreing Language Education, English Literature Programme. Her primary fields of study are British and American Fiction, Contemporary Literary Theory, Posthumanism, Humour, Children's Literature, Science-Fiction and Fantasy. Currently she is working on sound and rhythm in fiction exploring narratives that could be considered prose-poetry. ORCID: 0000-0001-5612-3665 